\title{
Ration formulations containing reduced-fat dried distillers grains with solubles and their effect on lactation performance, rumen fermentation, and intestinal flow of microbial nitrogen in Holstein cows
}

\author{
E. Castillo-Lopez, ${ }^{* 1}$ H. A. Ramirez Ramirez, ${ }^{\star}$ T. J. Klopfenstein, ${ }^{\star}$ D. Hostetler,† K. Karges,‡ S. C. Fernando, ${ }^{*}$ \\ and P. J. Kononoff*2 \\ ${ }^{*}$ Department of Animal Science, and \\ †Department of Veterinary and Biomedical Sciences, University of Nebraska-Lincoln, Lincoln 68583-0908 \\ ‡Dakota Gold Research Association, Sioux Falls, SD 57104-4506
}

\begin{abstract}
Sixteen multiparous lactating Holstein cows were used in 2 experiments to evaluate the effects of reducedfat dried distillers grains with solubles (RFDG) on milk production, rumen fermentation, intestinal microbial $\mathrm{N}$ flow, and total-tract nutrient digestibility. In experiment 1, RFDG was fed at 0,10, 20, or $30 \%$ of diet dry matter (DM) to 12 noncannulated Holstein cows (mean \pm standard deviation: $89 \pm 11 \mathrm{~d}$ in milk and $674 \pm$ $68.2 \mathrm{~kg}$ of body weight) to determine effects on milk production. In experiment 2, the same diets were fed to 4 ruminally and duodenally cannulated Holstein cows (mean \pm standard deviation: $112 \pm 41 \mathrm{~d}$ in milk; 590 $\pm 61.14 \mathrm{~kg}$ of body weight) to evaluate the effects on rumen fermentation, intestinal flow of microbial $\mathrm{N}$, and total-tract nutrient digestibility. In both experiments, cows were randomly assigned to $4 \times 4$ Latin squares over 21-d periods. Treatments (DM basis) were (1) control (0\% RFDG), (2) 10\% RFDG, (3) 20\% RFDG, and (4) $30 \%$ RFDG. Feed intake and milk yield were recorded daily. In both experiments, milk samples were collected on d 19 to 21 of each period for analysis of milk components. In experiment 2, ruminal $\mathrm{pH}$ was measured; samples of rumen fluid, duodenal digesta, and feces were collected on d 18 to 21. Microbial N was estimated by using purines and DNA as microbial markers. Milk yield was not affected by treatment and averaged $34.0 \pm 1.29 \mathrm{~kg} / \mathrm{d}$ and $31.4 \pm 2.81 \mathrm{~kg} / \mathrm{d}$ in experiments 1 and 2, respectively. Percentage of milk protein tended to increase in experiment 1; estimates were $3.08,3.18,3.15$, and $3.19 \pm 0.06 \%$ when RFDG increased from 0 to $30 \%$ in the diets. However, milk protein concentration was not affected in experiment 2 and averaged $3.02 \pm 0.07 \%$. Percentage of milk fat
\end{abstract}

Received March 28, 2013.

Accepted December 3, 2013.

${ }^{1}$ Current address: Department of Animal and Poultry Science, University of Saskatchewan, SK, S7N 5A8, Canada.

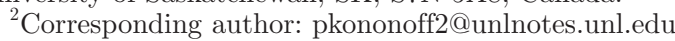

was not affected and averaged $3.66 \pm 0.05 \%$ and 3.25 $\pm 0.14 \%$ in experiments 1 and 2 , respectively. Total ruminal volatile fatty acids and ammonia concentrations were not affected by treatment and averaged $135.18 \pm 6.45 \mathrm{~m} M$ and $18.66 \pm 2.32 \mathrm{mg} / \mathrm{dL}$, respectively. Intestinal microbial $\mathrm{N}$ flow was not affected by treatment; however, purines yielded higher estimates of flow compared with DNA markers. When averaged across treatments, intestinal flow of microbial $\mathrm{N}$ was 303 and $218 \pm 18 \mathrm{~g}$ of $\mathrm{N} / \mathrm{d}$, using purines and DNA as the markers. Dry matter, organic matter, neutral detergent fiber, and nonfiber carbohydrate digestibility tended to increase with increasing inclusion of RFDG. Results from these experiments indicate that dairy rations can be formulated to include up to 30\% RFDG while maintaining lactation performance, volatile fatty acids concentration, and intestinal supply of microbial N.

Key words: distillers grains with solubles, lactation, intestinal microbial $\mathrm{N}$, total-tract nutrient digestibility

\section{INTRODUCTION}

Over the last decade, the supply of corn milling byproducts such as dried distillers grains with solubles (DDGS) has increased (Klopfenstein et al., 2008; Schingoethe et al., 2009). Over that time, extensive research has been conducted to evaluate the effect of this byproduct on lactational performance of dairy cows. A wide array of publications has reported that DDGS can be effectively fed to dairy cows while maintaining milk yield and composition. For example, Ranathunga et al. (2010) reported that, compared with a control diet, the inclusion of $21 \%$ DDGS in the ration had no negative effect on milk production or composition. Furthermore, Janicek et al. (2008) reported a linear increase in milk production when DDGS were included from 0 to $30 \%$ in dairy diets. Anderson et al. (2006) demonstrated that dairy rations may contain up to $20 \%$ DDGS, replacing an equal amount of both ground corn and soybean 
meal, and maintain or enhance milk production. Further research is needed to study effects not only on lactation performance, but also on rumen parameters, nutrient utilization, and intestinal microbial $\mathrm{N}$ supply. Recently, the corn milling industry has found new uses for corn oil, which is partially removed from the solubles stream by physical and chemical techniques (e.g., centrifugation or solvent extraction; Majoni et al., 2011); the resulting byproduct is commonly referred to as reduced-fat DDGS (RFDG; Mjoun et al., 2010a). With centrifugation technology, the RFDG product contains approximately $5.5 \%$ fat. Although the loss of fat may result in a product with less energy, it also contains a lower concentration of PUFA and thus may also lower the potential risk for the development of milk fat depression (Bauman and Griinari, 2003).

Several experiments have evaluated the effect of DDGS on microbial crude protein (MCP) synthesis. For example, Kelzer et al. (2009) reported that MCP synthesis was similar for cows fed a control diet with no DDGS, a diet containing 15\% DDGS, or a diet containing 15\% high-protein DDGS. Chibisa et al. (2012) demonstrated that wheat DDGS may substitute for canola meal as the major protein source in dairy cow diets without negatively affecting MCP production. Furthermore, Janicek et al. (2008) reported that MCP synthesis of cows consuming 30\% DDGS was similar compared with those consuming a diet containing no DDGS. Most of these studies have measured MCP by using purine derivatives as a microbial marker and measuring the concentration of this marker in the urine. Although the use of purine derivatives represents a noninvasive method to predict microbial $\mathrm{N}$ flow (Harmon and Richards, 1997), one limitation of using this method is thought to be the limited accuracy of the equations for prediction purposes (Firkins et al., 2006). In the present study, microbial $\mathrm{N}$ flow was measured in 2 ways: by the use of either purine bases or DNA as microbial markers. The objectives of these experiments were to evaluate the effects of increasing levels of RFDG on lactation performance, rumen fermentation, intestinal flow of microbial $\mathrm{N}$, and total-tract nutrient digestibility; and second to compare the estimates of microbial $\mathrm{N}$ using purine bases or DNA as microbial markers. We hypothesize that RFDG can be included in dairy rations with no negative effects on lactation performance, rumen fermentation, intestinal flow of microbial $\mathrm{N}$, or total-tract nutrient digestibility.

\section{MATERIALS AND METHODS}

This study was composed of 2 separate experiments. Experiment 1 was conducted to evaluate the effects of RFDG on lactation performance and was conducted at the Agriculture Research and Development Center of University of Nebraska-Lincoln (Mead). Experiment 2 was conducted to evaluate the effects of RFDG on rumen parameters, intestinal supply of microbial N, and total-tract nutrient digestibility and was conducted in the Dairy Metabolism Facility located in the Animal Science Complex of University of Nebraska-Lincoln (Lincoln). All experimental procedures were approved and cows were cared for according to the guidelines stipulated by the University of Nebraska Institutional Animal Care and Use Committee.

\section{Experiment 1: Experimental Design, Animal Care, and Sampling}

Twelve lactating multiparous Holstein cows (mean and SD, $89 \pm 11 \mathrm{DIM}$ and $674 \pm 68.2 \mathrm{~kg}$ of BW) were blocked by milk yield and DIM and randomly assigned to treatment sequences in replicated balanced $4 \times 4$ Latin squares according to the method of Kononoff and Hanford (2006) with 21-d periods. The first $14 \mathrm{~d}$ of each period were considered an adaptation period and the remaining $7 \mathrm{~d}$ were used for data collection. Cows were housed in individual tiestalls equipped with rubber mats and were offered 1 of 4 treatments that differed by the level of RFDG (Poet Nutrition, Sioux Falls, SD) inclusion: (1) control (CON), 0\% RFDG; (2) $10 \%$ RFDG; (3) 20\% RFDG; and (4) 30\% RFDG. The reported chemical composition of treatments is based upon analyzed chemical composition of individual feed ingredients. Treatments were formulated with the CPMDairy model (version 3.0.8.1; Cornell University, Ithaca, NY; University of Pennsylvania, Kennett Square, PA; and William H. Miner Agricultural Research Institute, Chazy, NY). A diet (CON) not containing RFDG was formulated and designed to be representative of a diet fed in the Great Plains of the United States. Then, a portion of forage, corn, cottonseed, and soy-based feeds were reduced to reach the greatest inclusion of RFDG, $30 \%$ of diet DM. Practically, formulations that substitute several ingredients are common when attempts are made to include byproducts. Consequently, formulations were similar in CP but the inclusion of RFDG resulted in a lower concentration of energy, as estimated by the CPM-Dairy model.

Cows were milked using a double- 5 herringbone parlor (BouMatic LLC, Madison, WI) at 0730 and 1930 $\mathrm{h}$, milk production was recorded, and milk samples were collected during the a.m. and p.m. milkings of d 19, 20, and 21. Milk samples were stored at room temperature in a vial containing a preserving pellet (2-bromo-2-nitropropane-1,3 diol,) provided by the DHIA (Manhattan, KS). Samples were then analyzed for fat, lactose, and true protein by near-infrared spec- 
troscopy (Bentley 2000 Infrared Milk Analyzer; Bentley Instruments, Chaska, MN) by Heart of America DHIA (Manhattan, KS). Chemical methodology based on a modified Berthelot reaction was used to determine MUN concentration (ChemSpec 150 Analyzer; Bentley Instruments). During the last $7 \mathrm{~d}$ of each period, daily DMI and milk yield were averaged.

Cows were individually fed once daily at $0930 \mathrm{~h}$ to allow for approximately $5 \%$ refusals using a Calan Data Ranger (American Calan Inc., Northwood, NH). Cows were allowed access to feed and fresh water at all times except during milking. Forages were premixed using a 354-12B mixer wagon (Roto-Mix LLC, Dodge City, KS). A control concentrate mix and an RFDGconcentrate mix were prepared. On the farm, the control- or RFDG-concentrate mix was added to the Calan Data Ranger after addition of the premixed forages to achieve 0 or $30 \%$ RFDG in the TMR. The intermediate diets were prepared by combining the control- and the RFDG-concentrate mix to achieve 10 or $20 \%$ RFDG in the TMR. Feed orts were collected and weighed daily to estimate intake for individual cows. Samples of corn silage, alfalfa haylage, alfalfa hay, brome hay, cottonseed, each concentrate mix, RFDG, and each TMR were collected on d 20 and 21 of each experimental period and stored at $-20^{\circ} \mathrm{C}$ until analysis. Dry matter concentrations of corn silage and alfalfa haylage were determined weekly by heating samples at $100^{\circ} \mathrm{C}$ for $24 \mathrm{~h}$. Using the resulting DM data, diets were then adjusted to ensure proper inclusion of ingredients in each treatment. Body condition score ( 1 to 5 scale) and BW were measured on d 20 and 21 of each period. Body condition score was measured by a single, trained individual, and the scoring method used was similar to that of Wildman et al. (1982), but reported to the quarter point.

\section{Experiment 2: Animal Surgeries, Experimental Design, Animal Care, and Sampling}

The second experiment was conducted separately after completion of experiment 1. Before initiation of this experiment, 4 multiparous Holstein cows averaging $172 \mathrm{~d}$ of gestation were fitted with T-shaped duodenal cannulas. Once cows had completely recovered from duodenal surgeries (approximately $60 \mathrm{~d}$ postsurgery), they were fitted with ruminal cannulas. Within the first 2 wk of the following lactation, these cows were transferred to the Dairy Metabolism Facility in the Animal Science Complex of University of Nebraska-Lincoln. At the start of the experiment cows averaged (mean $\pm \mathrm{SD}$ ) $112 \pm 41$ DIM and $590 \pm 61.14 \mathrm{~kg}$ of BW.

Duodenal Cannulations. Duodenal cannulations were performed according the procedures described by Robinson et al. (1985). Briefly, the right paralumbar fossa was anesthetized with a paravertebral nerve block using a modification of the Farquharson technique (Turner and McIlwraith, 1989). The right dorsal and ventral branches of the thoracic 13, lumbar 1 , and lumbar 2 were blocked with $20 \mathrm{~mL}$ of $2 \%$ lidocaine hydrochloride (Agri Laboratories Ltd., St Joseph, MO). In addition, recumbent anesthesia and sedation was induced (Anderson and Rings, 2009).

Upon becoming recumbent, the animal was positioned in left lateral recumbency with legs restrained forward and back. A 15-cm skin incision was made in the cranial paralumbar fossa parallel to the last rib with a \#20 scalpel. The external abdominal oblique, internal abdominal oblique, and transversus muscles and peritoneum were incised by sharp dissection. Upon entry to the abdomen, the pylorus and proximal $20 \mathrm{~cm}$ of the cranial part of the duodenum were exteriorized and separated from the remainder of the incision by moist towels. Site of cannula insertion was centered approximately $10 \mathrm{~cm}$ distal to the pylorus. The omentum was elevated from the duodenum for a distance corresponding to the length of the cannula barrel. Care was taken to preserve major branches of duodenal vessels, thus minimizing effects of cannulation on blood flow to the area. A 5- to 6-cm enterotomy was made along the right side of the duodenum in the area previously freed of omentum. The body of the double T-shaped cannula (Bar Diamond Inc., Parma ID) was inserted into the intestinal lumen. The enterotomy was closed adjacent to the barrel of the cannula with 2-0 polydioxanone in a simple interrupted pattern. The cut edges of the enterotomy were inverted and 2 purse-string sutures of the same type of suture material were placed snugly around the cannula barrel. In preparation for cannula exteriorization, a 2-cm-diameter piece of skin was removed from the right body wall in the 10th intercostal space at the level of the frontal plane of the shoulder joint. The cannula barrel was pushed through the body wall at this site and the outer collar was inserted to hold the cannula in place. The peritoneum and transversus were apposed in a simple continuous pattern with \#3 chromic gut on a $1 / 2$ circle taper needle. The internal and external abdominal muscles were apposed as a single layer in a simple continuous pattern with \#3 gut on a $1 / 2$ circle taper needle. The skin edges were apposed in a Ford continuous interlocking pattern with \#3 Braunamid suture (Aesculap Ag \& Co. a division of B. Braun, Melsungen, Germany) with an S-curved needle.

Cows were hospitalized and closely monitored until they recovered from the surgical procedure. Body temperature was taken once every day during the 10 d postsurgery. A single dose of $25 \mathrm{~mL}$ of Excenell or Exceed (Pfizer Inc., New York City, NY) was ad- 
ministered when body temperature exceeded normal range.

Ruminal Cannulations. Ruminal cannulations were conducted according to the procedure described by Noordsy and Ames (2006). Briefly, cows were restrained in a head gate with restraint chute. The left paralumbar fossa was anesthetized by blocking the left dorsal and ventral branches of the thoracic 13, lumbar 1, and lumbar 2 with $20 \mathrm{~mL}$ of $2 \%$ lidocaine hydrochloride (Agri Laboratories Ltd.).

After anesthesia was applied, a 17-cm linear skin incision was performed to place a 4 -inch rumen cannula (Bar Diamond Inc.) in the middle of the paralumbar fossa with a \#20 scalpel. The external abdominal oblique, internal abdominal oblique, and transversus muscles were incised parallel to their muscle fibers with sharp or blunt dissections. The peritoneum was entered by blunt dissection and then the peritoneal opening was extended to the size of the skin opening by sharp dissection. The rumen serosa was secured to the underside of the skin with interrupted horizontal mattress sutures. The rumen was resected with a $1-\mathrm{cm}$ margin from the suture line; the cannula was inserted and closed with a plug. Then, cows were returned to their normal diet and closely monitored during the 10 d postsurgery.

Housing of Cannulated Cows. Cows were housed in individual tiestalls having dimensions of $164 \mathrm{~cm}$ $\times 111 \mathrm{~cm}$ that were equipped with rubber mats. At the initiation of the trial, BW of cows was recorded; however, BW was not recorded during the experiment because of difficulties experienced when handling cows through the scale chute. Specifically, the scale chute was too narrow to handle the duodenally cannulated cows and there was a potential risk for cannula disruption by the panels of the chute. Cows were assigned to a single Latin square and randomly assigned to the experimental treatments. Rations were formulated to include the same levels of RFDG fed during experiment 1 . Cows were milked at 0700 and $1800 \mathrm{~h}$ using individual Delpro 480 DeLaval portable milking units through a pipeline system (DeLaval International AB, Tumba, Sweden). Milk samples were taken on the a.m. and p.m. milkings of d 18, 19, 20, and 21 and processed as described in experiment 1 . Cows were individually fed using a Calan Data Ranger; the feeding regimen and feed sample collection was conducted as described previously. Data on DMI and lactation performance were collected daily.

Measurement of Ruminal $\boldsymbol{p H}$. Ruminal $\mathrm{pH}$ was measured according to the protocol described by Penner et al. (2006). Briefly, during d 18 through 21 of each period ruminal $\mathrm{pH}$ was continuously measured once every minute using a wireless $\mathrm{pH}$ probe (Dascor
Inc., Escondido, CA) placed into the ventral sac of the rumen of each cow. Each probe contained a data logger, $9 \mathrm{~V}$ battery, and an electrode cable housed in a watertight capsule. Two 900-g weights were fastened to the bottom of the probe to maintain the electrode in the ventral sac of the rumen. The $\mathrm{pH}$ probes were calibrated with $\mathrm{pH}$ buffers 4 and 7 and recorded before inserting them into the rumen and after downloading $\mathrm{pH}$ data collected into calculation spreadsheets at the end of each period. The initialization of the data logger and the transfer of data were performed using a Windows-compatible software package (Microsoft Corp., Redmond, WA) supplied by Dascor (M1b version 6.1.2h). Ruminal pH measurements were averaged across the 4 collection days so that a period of $24 \mathrm{~h}$ beginning at $0930 \mathrm{~h}$ was represented. This starting time point was chosen given that TMR were offered at 0930 $\mathrm{h}$ after cows returned from a sand-surface exercise pen, where they were temporarily transferred during daily stall cleaning and TMR mixing. From the averaged pH data, the minimum, maximum, and mean ruminal $\mathrm{pH}$ were calculated for each cow. Because ruminal $\mathrm{pH}$ measurements in this experiment did not reach levels considered to indicate subacute (5.8) or acute ruminal acidosis (5.2; Aschenbach et al., 2011), thresholds of 6.5 and 6.3 were selected as references levels, and the time and area below these values were computed and are presented.

Ruminal Fluid and Intestinal Digesta Sampling. Ruminal fluid and intestinal digesta were collected on d 18 through 21 every $4 \mathrm{~h}$ in each experimental period. Whole rumen contents were collected from 4 different regions of the rumen (caudal ventral sac, cranial ventral sac, and 2 samples from the feed mat in the dorsal rumen) and composited. Rumen contents were then strained through 4 layers of cheesecloth; 40 $\mathrm{mL}$ of strained rumen fluid was placed in a $45-\mathrm{mL}$ vial and immediately frozen at $-20^{\circ} \mathrm{C}$ for later analyses for ruminal VFA and ammonia-N. Intestinal digesta contents $(200 \mathrm{~mL})$ were collected and placed in 250mL Nalgene bottles (Thermo Scientific Inc., Waltham, MA). Then, samples were composited by cow by day within period and frozen at $-20^{\circ} \mathrm{C}$ for subsequent analyses of intestinal flow of microbial N. Collection time of ruminal fluid and intestinal digesta samples was advanced $1 \mathrm{~h}$ in subsequent collection day, so that every 60 -min interval in a 24 -h period was represented (6 samples per cow per day and a total of 24 samples per cow per period). Specifically, samples were collected on d 18 at $0700,1100,1500,1900,2300$, and $0300 \mathrm{~h}$; on d 19 at $0800,1200,1600,2000,0000$, and $0400 \mathrm{~h}$; on d 20 at $0900,1300,1700,2100,0100$, and $0500 \mathrm{~h}$; and on d 21 at 1000, 1400, 1800, 2200, 0200, and $0600 \mathrm{~h}$. 
Collection of Ruminal Bacteria, Ruminal Protozoa, and Yeast Sample. On d 20 and 21 of each experimental period, $1.5 \mathrm{~L}$ of whole ruminal digesta contents was collected from 4 different locations within the rumen at 1000 and $1600 \mathrm{~h} \mathrm{(d} \mathrm{20)} \mathrm{and} 1200$ and $1800 \mathrm{~h}$ (d 21). Samples comprised equal volumes of rumen contents taken from the caudal ventral sac, cranial ventral sac, and 2 samples from the feed mat in the dorsal rumen. Then, mixed ruminal bacteria were isolated according to the procedure described by Hristov et al. (2005). Briefly, whole ruminal contents were composited and squeezed through 2 layers of cheesecloth and the filtrate was retained. Solids remaining on the cheesecloth were added to a volume of cold buffer (McDougall, 1948) equal to the volume of filtrate, and shaken manually in a screw-capped jar to dislodge the ruminal microorganisms loosely associated with feed particles. This suspension was then squeezed through 2 layers of cheesecloth and the 2 filtrates were combined (1:1) and preserved with 5\% (vol/vol) formalin. From this sample, bacteria were harvested via differential centrifugation (Hristov and Broderick, 1996) with an initial low-speed centrifugation at $400 \times g$ for $5 \mathrm{~min}$ at $4^{\circ} \mathrm{C}$ and a subsequent high-speed centrifugation at $20,000 \times g$ for $15 \mathrm{~min}$ at $4^{\circ} \mathrm{C}$. Samples were maintained on ice while being processed. Then, the supernatant was discarded and the isolated bacterial pellets were composited by cow and period and frozen at $-20^{\circ} \mathrm{C}$ for later analyses. Rumen protozoa were isolated using a separation funnel according to the procedure described by Shabi et al. (2000). Briefly, the strained ruminal digesta were mixed with 1 volume of warm $0.9 \%$ saline and held in a separation funnel for $1.5 \mathrm{~h}$ at $39^{\circ} \mathrm{C}$. The precipitate was then removed. The protozoal pellet was mixed with $500 \mathrm{~mL}$ of warm saline and kept in a separation funnel for another $1.5 \mathrm{~h}$ at $39^{\circ} \mathrm{C}$. Protozoa were then collected and frozen at $-20^{\circ} \mathrm{C}$. A sample of dried yeast cells (Saccharomyces cerevisiae) utilized in the ethanol production process was obtained and frozen at $-20^{\circ} \mathrm{C}$ until analysis.

Collection of Fecal Samples. Fecal grab samples (approximately $250 \mathrm{~g}$ ) were taken every $8 \mathrm{~h}$ on $\mathrm{d} 18$ to 21 of each period ( 3 samples per cow per day and a total of 12 samples per cow per period). Samples were then composited by cow, by day, within period. Then, samples were stored at $-20^{\circ} \mathrm{C}$ for later analysis of $\mathrm{Cr}_{2} \mathrm{O}_{3}$ and chemical composition.

\section{Analysis of Feed, Rumen Fluid, Duodenal Digesta, and Fecal Samples}

Feed Particle Size and Feed Chemical Analysis. The Penn State Particle Separator was used to measure the distribution of particle size of TMR according to
Heinrichs and Kononoff (2002). Collected feed ingredients and TMR samples were dried for $48 \mathrm{~h}$ at $60^{\circ} \mathrm{C}$ in a forced-air oven, ground to pass through a $1-\mathrm{mm}$ screen (Wiley mill, Arthur H. Thomas Co., Philadelphia, PA) and analyzed for chemical composition by an external laboratory (Cumberland Valley Analytical Services, Hagerstown, MD), which included DM (method no. 930.15; AOAC International, 2000), N (method no. 990.03; Leco FP-528 Nitrogen Combustion Analyzer, Leco Corp. St. Joseph, MI), NDF (Van Soest et al., 1991), starch (Hall, 2009), ether extract using diethyl ether (method no. 2003.05; AOAC International, 2006), ash (method no. 942.05; AOAC International, 2000) and phosphorus by inductively coupled plasma emission spectroscopy (method no. 985.01; AOAC International, 2000). In addition, the concentration of yeast (S. cerevisiae) protein was measured from subsamples of collected RFDG. This was conducted by using DNA markers as described by Castillo-Lopez et al. (2010).

Ruminal VFA Analysis. At the end of experiment 2,10 samples of rumen fluid collected from each cow in each period (over the course of the $4 \mathrm{~d}$ and representing a 24-h period) were analyzed for VFA by an external laboratory (Rumen Fermentation Profiling Laboratory, West Virginia University, Morgantown). Specifically, rumen samples analyzed for VFA were those collected at 1000, 1100, 1200, 1400, 1600, 1800, 2100, 0000, 0400, and $0900 \mathrm{~h}$. Briefly, analysis of VFA concentrations in effluents was performed according to the gas chromatographic separation procedure (Supelco Inc., 1975). The gas chromatograph was a Varian model 3300 with a flame-ionization detector (Varian Inc., Palo Alto, CA). The column was a $2-\mathrm{m} \times 2-\mathrm{mm}$ glass column packed with $10 \%$ SP-1200/1\% $\mathrm{H}_{3} \mathrm{HPO}_{4}$ on 80/100 Chromosorb WAW (Supelco Inc., Bellefonte, PA).

Ruminal Ammonia Analysis. A portion of the 10 samples of rumen fluid analyzed for VFA were also analyzed for ammonia- $\mathrm{N}$ concentration using a phenolhypochlorite assay (Yang and Varga, 1989). Briefly, 1.5 $\mathrm{mL}$ of rumen fluid was centrifuged at 11,000 $\times g$ for 20 min at $4^{\circ} \mathrm{C}$ and then $40 \mu \mathrm{L}$ of supernatant was taken in duplicate and combined with 2.5 and $2.0 \mathrm{~mL}$ of phenol color reagent and alkaline hypochlorite reagent, respectively. After incubation for $10 \mathrm{~min}$ at $37^{\circ} \mathrm{C}, 300 \mu \mathrm{L}$ of sample was taken and place in a 96-well polystyrene plate (Becton Dickinson and Company, Franklin Lakes, NJ) and absorbance was read at $550 \mathrm{~nm}$. Analysis was repeated whenever the coefficient of variation between duplicates exceeded $4.9 \%$.

Intestinal Flow of Microbial N Using Purines as Microbial Marker. Collected duodenal contents were lyophilized and ground to pass through a 1-mm screen using a Wiley mill (Arthur H. Thomas). Then, ground samples were analyzed for $\mathrm{DM}\left(100^{\circ} \mathrm{C}\right.$ oven for 
$24 \mathrm{~h}$ ). Subsamples of isolated ruminal bacterial pellets were ground with a mortar and pestle and analyzed for N (AOAC International, 2006; method no. 990.03; Leco FP-528 Nitrogen Combustion Analyzer, Leco Corp.).

Purines (Zinn and Owens, 1986; Broderick and Merchen, 1992) were used as a microbial marker to measure duodenal flow of total microbial N. The analysis of purines was conducted according to the procedure described by Makkar and Becker (1999). Briefly, approximately $50 \mathrm{mg}$ of lyophilized microbial and duodenal samples were placed in Pyrex screw-cap tubes. Then, samples were combined with $0.5 \mathrm{~mL}$ of allopurinol internal standard ( $3 \mathrm{mM}$ allopurinol) and $2.5 \mathrm{~mL}$ of $0.6 \mathrm{M} \mathrm{HClO}_{4}$ and incubated for $1 \mathrm{~h}$. After samples cooled, they were combined with $7.5 \mathrm{~mL}$ of $10 \mathrm{mM}$ $\mathrm{NH}_{4} \mathrm{H}_{2} \mathrm{PO}$, and the $\mathrm{pH}$ was adjusted to between 6.6 and 6.9 using concentrated $\mathrm{KOH}(8 \mathrm{M})$. After centrifugation of samples $(3,000 \times g$ for $10 \mathrm{~min})$, the supernatant was filtered through a $13-\mathrm{mm}$ disposable syringe filter (0.45- $\mu \mathrm{m}$ pore size) with a GHP membrane (Whatman Inc., Florham Park, NJ) into an HPLC vial. Total purines were measured using a 717 HPLC system (Waters Corp. Inc., Milford, MA). Calculation of microbial N was based on the ratio of purine:N obtained from the isolated rumen bacterial pellet and on the concentration of purines in duodenal samples.

Intestinal Flow of Microbial $N$ Using DNA as Microbial Marker. The use of DNA markers for the estimation of microbial $\mathrm{N}$ flow has been reported elsewhere (Belanche et al., 2011b). In this study, the sum of bacterial and protozoal $\mathrm{N}$ was considered as microbial N. Separate estimates of bacterial N and protozoal $\mathrm{N}$ were measured based on (1) the ratio of DNA marker: $\mathrm{N}$ in the isolated bacterial or protozoal pellet and (2) the abundance of the targeted bacterial or protozoal DNA marker measured from duodenal samples. From those values, the amount of $\mathrm{N}$ originating from bacteria and protozoa was calculated. To do so, subsamples of isolated bacterial and protozoal pellets were analyzed for DM by heating samples at $100^{\circ} \mathrm{C}$ for $24 \mathrm{~h}$ (method no. 930.15; AOAC International, 2000) and N (method no. 990.03; AOAC International, 2006; Leco FP-528 Nitrogen Combustion Analyzer, Leco Corp.). Then, DNA was extracted from the remaining portion of the pellets and from digesta samples according to the extraction method for PCR-quality DNA from digesta samples described by $\mathrm{Yu}$ and Morrison (2004). The concentration of DNA $(\mathrm{ng} / \mu \mathrm{L})$ in each sample was measured by spectrophotometry (NanoDrop ND1000 Spectrophotometer, NanoDrop Technologies Inc., Wilmington, DE) and stored at $-20^{\circ} \mathrm{C}$ in aliquots of $25 \mu \mathrm{L}$ for later analysis using real-time PCR. The same approach was conducted for the calculation of yeastbased $\mathrm{N}$ flow.
Bacterial, protozoal, and yeast DNA markers utilized, real-time PCR reactions, and calculations of marker abundance have been described elsewhere (Yu et al., 2005; Castillo-Lopez et al., 2013). Briefly, for each microbial type, $4 \mu \mathrm{L}$ of DNA sample was combined with $1 \mu \mathrm{L}$ of $10 \mu M$ forward primer, $1 \mu \mathrm{L}$ of $10 \mu M$ reverse primer, $0.25 \mu \mathrm{L}$ of $10 \mu M$ TaqMan probe, $7.5 \mu \mathrm{L}$ of TaqMan Master Mix (Applied Biosystems, Foster City, $\mathrm{CA}$ ), and $1.25 \mu \mathrm{L}$ of nanopure water. Two samples with no DNA were included and used as nontemplate controls. Each sample was run in duplicate in separate wells of the 384-well, real-time PCR plate.

Duodenal Digesta Flow and Total-Tract Digestibility Measurements. Chromic oxide $\left(\mathrm{Cr}_{2} \mathrm{O}_{3}\right)$ was used as an external marker. Briefly, $7.5 \mathrm{~g}$ of $\mathrm{Cr}_{2} \mathrm{O}_{3}$ was weighed (Taylor and Allen, 2005) and placed in gelatin capsules (Torpac Inc., Fairfield, NJ). Then, the capsules were dosed into the rumen via the ruminal cannula twice daily at 0700 and $1900 \mathrm{~h}$ from d 10 through 21 of each experimental period. Because of greater than expected variation obtained in the concentration of $\mathrm{Cr}_{2} \mathrm{O}_{3}$ in duodenal samples, indigestible ADF (iADF) was used as the digesta marker (Huhtanen et al., 1994) for the estimation of intestinal DM and microbial $\mathrm{N}$ flow. The use of iADF as a single digesta marker was based on reports made by other researchers (Kelzer et al., 2009; Ramirez-Ramirez et al., 2011). The TMR and duodenal samples were weighed $(2 \mathrm{~g})$ into $5 \times$ $10 \mathrm{~cm}$ Dacron bags with 50- $\mu \mathrm{m}$ pores (No. R510; Ankom Technology, Fairport, NY). The concentration of iADF in samples was determined after a 288 -h in situ incubation in the rumen using 2 cows being fed a diet containing $60 \%$ forage and $40 \%$ concentrate. To estimate fecal output and total-tract nutrient digestibility, however, $\mathrm{Cr}_{2} \mathrm{O}_{3}$ (Harvatine et al., 2002; Sylvester et al., 2005 ) was used as the digesta marker and yielded fairly consistent values. Collected fecal samples were composited by cow, by day, within period. Samples were oven-dried $\left(60^{\circ} \mathrm{C}\right.$ for $\left.48 \mathrm{~h}\right)$ and ground to pass through a 1-mm screen (Wiley mill, Arthur H. Thomas Co.). Dried fecal samples were analyzed by an external laboratory for chemical composition (Cumberland Valley Analytical Services, Hagerstown, MD). Fecal samples were analyzed for chromium concentration by an external laboratory (Servi-Tech Laboratories, Hastings, $\mathrm{NE}$ ) by sample digestion in $10 \mathrm{~mL}$ of nitric acid and $3 \mathrm{~mL}$ of peroxide, with a hydrochloric acid addition and analyzed by inductively coupled plasma emission spectroscopy using a Varian 720-ES spectrophotometer (Varian Inc.). Digesta flow to the duodenum or rectum was calculated based on the amount of the marker fed (iADF) or dosed $\left(\mathrm{Cr}_{2} \mathrm{O}_{3}\right)$ and the concentration of the respective marker in duodenal or fecal sample (Harvatine et al., 2002). Apparent total-tract digestion of 
DM, OM, NFC, NDF, N, and P were calculated as follows: [(intake of nutrient - fecal output of nutrient)/ intake of nutrient] $\times 100$ (May et al., 2010).

\section{Experiment 1: Statistical Analysis}

Performance data were analyzed as replicated balanced $4 \times 4$ Latin squares using the MIXED procedures of SAS (version 9.1, SAS Institute Inc., Cary, NC). Fixed model effects included square, period within square, and treatment, and the random effect was cow within square. Linear and quadratic effects of treatments were tested. The model for this experiment was as follows:

$$
\mathrm{Y}_{\mathrm{ijkm}}=\mu+\tau_{\mathrm{m}}+\beta(\tau)_{\mathrm{im}}+\rho(\tau)_{\mathrm{jm}}+\alpha_{\mathrm{k}}+\varepsilon_{\mathrm{ijkm}},
$$

where $Y_{i j k m}$ represents observation ijkm; $\mu$ represents the overall mean; $\tau_{\mathrm{m}}$ represents the fixed effect of square $\mathrm{m} ; \beta(\tau)_{\text {im }}$ represents the random effect of cow $\mathrm{i}$ within square $m ; \rho(\tau)_{j m}$ represents the fixed effect of period $j$ within square $\mathrm{m}$; and $\alpha_{\mathrm{k}}$ represents the fixed effect of treatment $\mathrm{k}$. The residual term $\varepsilon_{\mathrm{ijkm}}$ was assumed to be normally, independently, and identically distributed, with variance $\sigma_{e}^{2}$.

\section{Experiment 2: Statistical Analysis}

Data collected on lactation performance, rumen $\mathrm{pH}$, and duodenal flow were analyzed as a $4 \times 4$ Latin square using the MIXED procedure of SAS (version 9.1; SAS Institute Inc.). Fixed model effects included treatment and period, with cow as the random effect. The model for this experiment was as follows:

$$
\mathrm{Y}_{\mathrm{ijk}}=\mu+\beta_{\mathrm{i}}+\rho_{\mathrm{j}}+\alpha_{\mathrm{k}}+\varepsilon_{\mathrm{ijk}},
$$

where $Y_{\mathrm{ijk}}$ represents observation ijk; $\mu$ represents the overall mean; $\beta_{\mathrm{i}}$ represents the random effect of cow i; $\rho_{\mathrm{j}}$ represents the fixed effect of period $\mathrm{j}$; and $\alpha_{\mathrm{k}}$ represents the fixed effect of treatment $k$. The residual term $\varepsilon_{\mathrm{ijk}}$ was assumed to be normally, independently, and identically distributed, with variance $\sigma_{e}^{2}$.

For experiment 2, repeated measurements of rumen ammonia and VFA concentration were analyzed by including a REPEATED model statement, and linear and quadratic effects of treatments were also tested. Treatment means are presented as least squares means and the largest standard error of the mean (SEM) is reported. Statistical significance was declared at $P$ $\leq 0.05$ and tendency was declared if $P>0.05$ and $\leq 0.15$.

\section{RESULTS}

\section{Feed Chemical Composition and TMR Particle Size Distribution}

The ingredient composition of experimental treatments fed in experiments 1 and 2 is listed in Table 1 . The chemical composition of those treatments is listed in Table 2. Table 3 lists the chemical composition of feed ingredients utilized in the formulation of treatments. Rations contained similar levels of $\mathrm{CP}$ and fat. However, the level of NDF increased from 34 to $37 \%$ with the highest inclusion of RFDG in the diets. In contrast, the percentage of starch decreased from 26 to $17 \%$ with increasing levels of RFDG in treatments. The particle size distribution of dietary treatments fed in both experiments is listed in Table 4. In experiment 1 , a linear decrease $(P<0.01)$ of TMR particle size was observed with the inclusion of RFDG. Specifically, the proportion of particles $>19.0 \mathrm{~mm}$ decreased from 9.38 to $6.75 \%$, the proportion of particles between 19.0 and $8.0 \mathrm{~mm}$ decreased from 25.58 to $19.89 \%$, and the proportion of particles between 8.0 and $1.18 \mathrm{~mm}$ decreased from 37.86 to $30.20 \%$. However, the proportion of particles $<1.18 \mathrm{~mm}$ increased from 27.16 to $43.14 \%$. In experiment 2, a similar pattern in TMR particle size distribution was observed. We found a linear decrease $(P<0.05)$ of TMR particle size with the inclusion of RFDG. Specifically, the proportion of particles $>19.0$ $\mathrm{mm}$ decreased from 6.50 to $3.64 \%$, the proportion of particles between 19.0 and $8.0 \mathrm{~mm}$ decreased from 26.20 to $18.01 \%$, and the proportion of particles between 8.0 and $1.18 \mathrm{~mm}$ decreased from 39.10 to $32.06 \%$. However, the proportion of particles $<1.18 \mathrm{~mm}$ increased from 27.51 to $46.35 \%$ when the inclusion of RFDG increased from 0 to $30 \%$.

\section{DMI, BW, BCS, and Lactation Performance}

Data collected in experiment 1 on DMI, BW, BCS, and lactation performance are listed in Table 5. Table 6 lists DMI and lactation performance data collected in experiment 2. In experiment 1, total DMI increased linearly $(P<0.01)$ with the inclusion of RFDG. Total DMI was $25.0,23.8,25.9$, and $27.9 \pm 1.38 \mathrm{~kg} / \mathrm{d}$ for CON, 10, 20, and 30\% RFDG, respectively. In this experiment, an increase in BW $(P<0.01)$ and BCS $(P=$ 0.05) was also observed with the inclusion of RFDG in diets. Average BW was 687.2, 687.8, 693.4, and 696.7 $\pm 18.4 \mathrm{~kg}$, and BCS was $3.06,3.10,3.14$, and $3.18 \pm$ 0.06 for CON, 10, 20, and 30\% RFDG, respectively. In experiment 2 , total DMI was not affected $(P=0.73)$ by the inclusion of RFDG, which averaged $21.56 \pm 1.65$ $\mathrm{kg} / \mathrm{d}$ across treatments. 
Table 2. Analyzed chemical composition (\% of DM unless otherwise noted) of diets containing increasing levels (0 to 30\%) of reduced-fat dried distillers grains with solubles (RFDG; Poet Nutrition, Sioux Falls, SD) fed in experiment 1 and 2

\begin{tabular}{|c|c|c|c|c|}
\hline \multirow{2}{*}{$\begin{array}{l}\text { Chemical composition }{ }^{1} \\
\text { (\% of DM) }\end{array}$} & \multicolumn{4}{|c|}{ Treatment } \\
\hline & Control $(0 \%)$ & $10 \%$ RFDG & $20 \%$ RFDG & $30 \%$ RFDG \\
\hline \multicolumn{5}{|l|}{ Experiment 1} \\
\hline DM & 71.3 & 72.0 & 73.3 & 75.3 \\
\hline $\mathrm{CP}$ & 18.3 & 18.2 & 18.1 & 18.0 \\
\hline $\mathrm{NDF}$ & 35.4 & 36.5 & 37.9 & 38.3 \\
\hline Starch & 24.7 & 22.3 & 20.0 & 17.6 \\
\hline Ether extract & 3.9 & 4.0 & 4.0 & 4.1 \\
\hline $\mathrm{NFC}^{2}$ & 34.0 & 33.1 & 32.1 & 30.7 \\
\hline Ash & 8.1 & 8.2 & 8.3 & 8.4 \\
\hline Phosphorous & 0.36 & 0.41 & 0.46 & 0.52 \\
\hline $\mathrm{ME}^{3}$ (Mcal $/ \mathrm{kg}$ ) & 2.53 & 2.51 & 2.49 & 2.47 \\
\hline $\mathrm{NE}_{\mathrm{I}}{ }^{3}(\mathrm{Mcal} / \mathrm{kg})$ & 1.63 & 1.62 & 1.60 & 1.59 \\
\hline $\mathrm{RUP}^{3}(\%$ of CP) & 41.47 & 43.02 & 45.91 & 49.04 \\
\hline \multicolumn{5}{|l|}{ Experiment 2} \\
\hline DM & 73.4 & 74.2 & 75.9 & 76.2 \\
\hline $\mathrm{CP}$ & 18.3 & 18.2 & 18.2 & 18.2 \\
\hline $\mathrm{NDF}$ & 33.3 & 34.5 & 36.2 & 37.3 \\
\hline Starch & 25.8 & 22.9 & 20.1 & 17.2 \\
\hline Ether extract & 4.0 & 4.2 & 4.3 & 4.4 \\
\hline $\mathrm{NFC}^{2}$ & 35.9 & 34.8 & 33.7 & 31.8 \\
\hline Ash & 8.3 & 8.4 & 8.4 & 8.5 \\
\hline Phosphorous & 0.35 & 0.40 & 0.44 & 0.51 \\
\hline $\mathrm{ME}^{3}(\mathrm{Mcal} / \mathrm{kg})$ & 2.58 & 2.56 & 2.53 & 2.51 \\
\hline $\mathrm{RUP}^{3}$ & 41.66 & 42.26 & 44.22 & 49.29 \\
\hline
\end{tabular}

${ }^{1}$ Calculated based on analysis of individual feed ingredient and the rate of inclusion to the diet.

${ }^{2}$ Calculated by difference: $100-(\% \mathrm{NDF}+\% \mathrm{CP}+\%$ fat $+\%$ ash $)$.

${ }^{3}$ According to the CPM Dairy Ration Analyzer v3.0.8.1 (Cornell University, Ithaca, NY; University of Pennsylvania, Kennett

Square, PA; and Wiliam H. Miner Agricultural Research Institute, Chazy, NY).

Figure 1 illustrates ruminal $\mathrm{pH}$ measurements collected and averaged over the course of $4 \mathrm{~d}$. In addition, Table 7 lists minimum, maximum, and mean ruminal $\mathrm{pH}$ values as well as time and area below $\mathrm{pH} 6.5$ and 6.3. A decrease $(P=0.02)$ in mean ruminal $\mathrm{pH}$ was observed with RFDG inclusion, with estimates of 6.53 , $6.49,6.38$, and $6.35 \pm 0.12$ for CON, 10, 20, and $30 \%$ RFDG, respectively. The time $(P<01)$ and area $(P=$ 0.03 ) below $\mathrm{pH} 6.5$ increased: estimates of time below $\mathrm{pH} 6.5$ were $546,834,941$, and $1,040 \pm 293 \mathrm{~min} / \mathrm{d}$ and estimates of area below pH 6.5 were 126, 158, 357, and $334 \pm 92 \mathrm{pH} \times \mathrm{min} / \mathrm{d}$, for CON, 10, 20, and $30 \%$ RFDG, respectively. Furthermore, the time below $\mathrm{pH}$ 6.3 increased $(P=0.03)$ : estimates were $279,382,936$, and $946 \pm 208 \mathrm{~min} / \mathrm{d}$, respectively. The area below $\mathrm{pH}$ 6.3 tended to increase $(P=0.13)$, with estimates of 45 , 47, 180, and $169 \pm 64 \mathrm{pH} \times \mathrm{min} / \mathrm{d}$, respectively.

\section{Apparent Total-Tract Nutrient Digestibility of TMR}

Total-tract digestibility of major nutrients tended to increase with RFDG inclusion (Table 8). Estimates of total-tract DM digestibility $(P=0.14)$ were 65.5 , $65.4,73.0$, and $73.4 \pm 4.8 \%$ for CON 10,20 , and $30 \%$ RFDG, respectively. In the same order, estimates of
OM digestibility $(P=0.14)$ were $67.7,67.7,74.9$, and $75.2 \pm 4.4 \%$. Estimates of NFC digestibility $(P=0.07)$ were $89.7,90.1,92.6$, and $92.7 \pm 1.2 \%$. Estimates of NDF digestibility $(P=0.11)$ were $44.0,43.2,57.0$, and $58.0 \pm 7.5 \%$. Estimates of $\mathrm{N}$ digestibility $(P=0.06)$ were $64.3,67.7,74.7$, and $76.9 \pm 5.1 \%$. In addition, Table 8 lists the output of $\mathrm{N}$ and $\mathrm{P}$. The output of $\mathrm{N}$ $(\mathrm{kg} / \mathrm{d})$ was $0.202,0.197,0.152$, and $0.146 \pm 0.02(P=$ $0.09)$; the output of $\mathrm{P}(\mathrm{g} / \mathrm{d})$ was $46,54,53$, and $53 \pm$ $7.1(P=0.49)$.

\section{Intestinal Flow of DM, Total N, and Microbial N}

Table 9 lists intestinal flow and apparent ruminal digestibility of DM as well as intestinal flow of total $\mathrm{N}$ and microbial N. Intestinal flow $(P=0.41)$ and apparent ruminal digestibility $(P=0.38)$ of $\mathrm{DM}$ were not affected by treatment and averaged $15.2 \pm 1.4 \mathrm{~kg} / \mathrm{d}$ and $29.8 \pm 3.2 \%$, respectively. Intestinal flow of total $\mathrm{N}$ was not affected $(P=0.55)$ by treatment and averaged $594.7 \pm 68.0 \mathrm{~g} / \mathrm{d}$. Likewise, the flow of microbial $\mathrm{N}$ was not affected by treatment when estimated using purines $(P=0.47)$ or DNA $(P=0.65)$ markers. However, when averaged across treatments, purines yielded higher $(P<0.01)$ microbial $\mathrm{N}$ flow compared with 
Table 3. Analyzed chemical composition (mean \pm SD) of feedstuffs used in the formulation of diets containing increasing levels of reduced-fat dried distillers grains with solubles (RFDG; Poet Nutrition, Sioux Falls, SD) fed in experiments 1 and 2

\begin{tabular}{|c|c|c|c|c|c|c|c|c|}
\hline Component & \multicolumn{8}{|c|}{ Feed ingredient } \\
\hline DM & $32.83 \pm 1.04$ & $32.50 \pm 2.58$ & $88.25 \pm 0.86$ & $87.80 \pm 0.88$ & $89.20 \pm 1.49$ & $90.30 \pm 0.14$ & $88.98 \pm 0.74$ & $90.53 \pm 0.62$ \\
\hline $\mathrm{CP}$ & $8.70 \pm 0.42$ & $22.00 \pm 0.72$ & $10.25 \pm 0.60$ & $20.68 \pm 1.18$ & $21.98 \pm 1.46$ & $31.85 \pm 0.49$ & $21.80 \pm 0.37$ & $20.88 \pm 0.51$ \\
\hline $\mathrm{NDF}$ & $39.30 \pm 1.28$ & $42.85 \pm 2.07$ & $69.85 \pm 4.13$ & $41.88 \pm 1.70$ & $48.60 \pm 2.20$ & $33.90 \pm 3.54$ & $25.03 \pm 1.72$ & $34.77 \pm 0.25$ \\
\hline $\mathrm{NFC}^{3}$ & $43.31 \pm 1.21$ & $20.04 \pm 2.55$ & $8.42 \pm 3.72$ & $24.03 \pm 1.72$ & $5.54 \pm 1.29$ & $22.75 \pm 4.44$ & $42.30 \pm 1.43$ & $31.76 \pm 0.55$ \\
\hline Ash & $5.86 \pm 0.31$ & $11.98 \pm 0.39$ & $9.44 \pm 0.42$ & $11.64 \pm 0.95$ & $4.32 \pm 0.42$ & $5.98 \pm 0.91$ & $8.22 \pm 0.20$ & $8.56 \pm 0.20$ \\
\hline $\begin{array}{l}\text { Phosphorous } \\
\text { YCP }^{4}\end{array}$ & $0.32 \pm 0.03$ & $0.32 \pm 0.01$ & $0.30 \pm 0.01$ & $0.30 \pm 0.03$ & $0.61 \pm 0.04$ & $\begin{array}{l}0.99 \pm 0.05 \\
1.97 \pm 0.04\end{array}$ & $0.37 \pm 0.02$ & $0.64 \pm 0.03$ \\
\hline \multicolumn{9}{|l|}{ Experiment 2} \\
\hline $\mathrm{DM}$ & $35.32 \pm 2.52$ & $50.24 \pm 2.83$ & $87.98 \pm 1.33$ & $86.70 \pm 1.77$ & $88.74 \pm 0.98$ & $90.25 \pm 0.21$ & $88.52 \pm 0.62$ & $91.16 \pm 1.36$ \\
\hline $\mathrm{CP}$ & $8.28 \pm 0.40$ & $22.38 \pm 1.03$ & $10.34 \pm 0.58$ & $19.40 \pm 2.46$ & $21.72 \pm 1.14$ & $32.05 \pm 0.21$ & $21.98 \pm 0.80$ & $21.18 \pm 0.70$ \\
\hline $\begin{array}{l}\text { Phosphorous } \\
\text { YCP }^{4}\end{array}$ & $0.28 \pm 0.02$ & $0.24 \pm 0.01$ & $0.30 \pm 0.01$ & $0.30 \pm 0.03$ & $0.65 \pm 0.02$ & $\begin{array}{l}0.96 \pm 0.01 \\
1.91 \pm 0.04\end{array}$ & $0.38 \pm 0.02$ & $0.63 \pm 0.02$ \\
\hline
\end{tabular}

${ }^{1}$ Contained $46.8 \%$ ground corn, $20.6 \%$ soyhulls, $12.5 \%$ Soypass (LignoTech, Overland Park, KS), $12.9 \%$ soybean meal, $2.1 \%$ blood meal, $2.3 \%$ limestone-ground, $0.9 \%$ sodium bicarbonate, $0.5 \%$ salt, magnesium oxide, $0.2 \%$ trace mineral premix and $0.2 \%$ vitamin premix.

${ }^{2}$ Contained $48.5 \%$ RFDG, $16.5 \%$ ground corn, $25.7 \%$ soyhulls, $2.3 \%$ Soypass (LignoTech), 3.0\% Megalac (Church \& Dwight Co. Inc., Princeton, NJ), $1.8 \%$ limestone-ground, $0.8 \%$ sodium bicarbonate, $0.8 \%$ salt, $0.4 \%$ magnesium oxide, $0.19 \%$ trace mineral premix and $0.19 \%$ vitamin premix.

${ }^{3}$ Calculated by difference: $100-(\% \mathrm{NDF}+\% \mathrm{CP}+\%$ fat $+\%$ ash $)$.

${ }^{4} \mathrm{YCP}=$ yeast crude protein determined by real-time PCR according to Castillo-Lopez et al. (2010).

DNA markers; averages were 303.0 and $218.0 \pm 18.0$ g of $\mathrm{N} / \mathrm{d}$, for purines and DNA markers, respectively. Intestinal protozoal $\mathrm{N}$ flow was not affected $(P=0.51)$ by treatment and averaged $40.7 \pm 13.7 \mathrm{~g}$ of $\mathrm{N} / \mathrm{d}$. Intestinal yeast $\mathrm{N}$ flow, however, increased $(P<0.01)$ with RFDG inclusion; estimates were $0.09,0.96,1.20$, and $2.50 \pm 0.33 \mathrm{~g}$ of $\mathrm{N} / \mathrm{d}$ for CON, 10, 20, and $30 \% \mathrm{RFDG}$, respectively.
DISCUSSION

\section{Lactation Performance and DMI}

Potential challenges related to milk fat depression have been suggested when including regular DDGS in dairy rations because of its high content of unsaturated fatty acids (Bauman and Griinari, 2003; Hollmann et al., 2011); therefore, feeding RFDG may reduce these

Table 4. Particle size distribution (\% retained, as fed) of formulated diets containing increasing levels (0 to $30 \%)$ of reduced-fat dried distillers grains with solubles (RFDG; Poet Nutrition, Sioux Falls, SD) fed in experiments 1 and 2

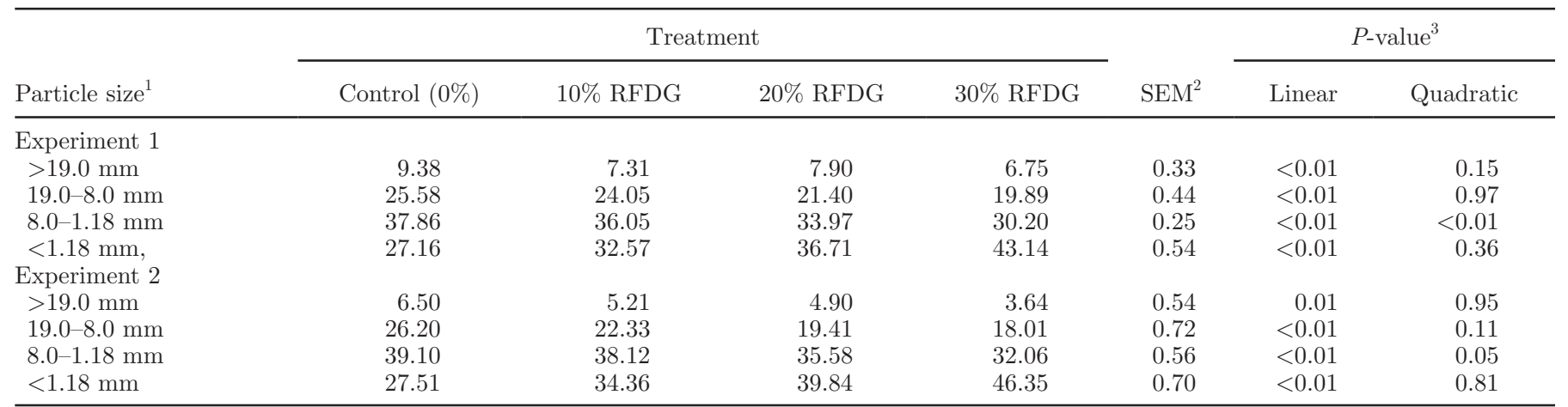

${ }^{1}$ Determined using the Penn State Forage Particle Separator as described by Heinrichs and Kononoff (2002).

${ }^{2}$ The highest standard error of treatment means is shown.

${ }^{3} P$-values for effects of increasing levels of DDGS in diet. 
Table 5. Effects of feeding increasing levels (0 to 30\%) of reduced-fat dried distillers grains with solubles (RFDG; Poet Nutrition, Sioux Falls, $\mathrm{SD})$ on DMI, milk production and milk composition (experiment 1)

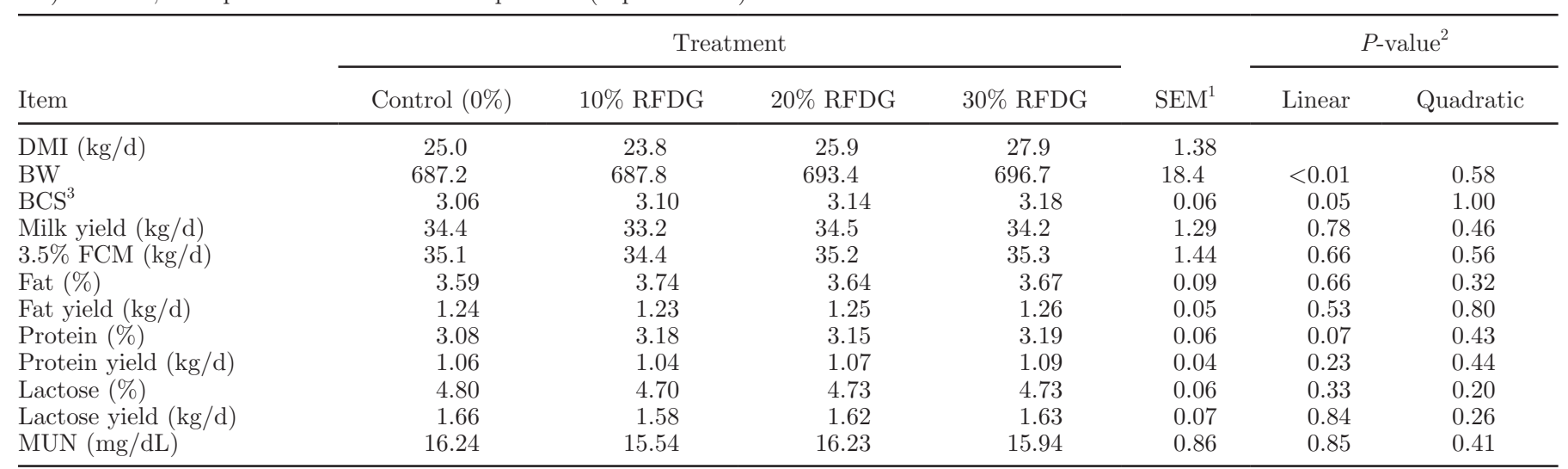

${ }^{1}$ The highest standard error of treatment means is shown.

${ }^{2} P$-values for effects of increasing levels of RFDG in diet.

${ }^{3} \mathrm{On}$ a 1 to 5 scale.

challenges. Our results support this concept and agree with data reported previously (Mjoun et al., 2010a,b) in that the inclusion of RFDG in rations of lactating dairy cows had no negative effect on yield or percentage milk fat and tended to increase the percentage of milk protein. Therefore, this study confirms that RFDG is an effective feed ingredient that can be included in rations formulated for dairy cows without affecting production performance.

The increase in DMI observed in experiment 1 may reflect greater palatability of diets containing RFDG compared with CON and may also be a consequence of the reduction in TMR particle size with RFDG inclusion. In conjunction with decreasing particle size, the percentage of forages (consisting of corn silage, alfalfa haylage, brome hay, and alfalfa hay) decreased from 45.7 to $35.8 \%$ as RFDG increased from 0 to $30 \%$. This decrease in forage NDF along with a decrease in TMR particle size allowed more feed to be consumed before reaching rumen fill (Allen and Grant, 2000; Janicek et al., 2008). In addition, based on the CPM Dairy model predictions, the concentration of ME of diets decreased from 2.53 to $2.47 \mathrm{Mcal} / \mathrm{kg}$ when RFDG increased from 0 to $30 \%$, possibly because of the reduction in the level of NFC in the rations. Therefore, the increase in DMI may have been a response to compensate for the lower $\mathrm{ME}$ ration being consumed and to provide enough nutrients that the cows need for lactation.

\section{VFA and Ruminal pH}

The relative concentration of individual ruminal VFA can affect milk composition (Thomas and Martin, 1988). Specifically, increases in supply of acetic acid are associated with increased milk yield and milk fat concentration, and increases in supply of butyric acid

Table 6. Effects of feeding increasing levels (0 to 30\%) of reduced-fat dried distillers grains with solubles (RFDG; Poet Nutrition, Sioux Falls, $\mathrm{SD})$ on DMI, milk production and milk composition (experiment 2)

\begin{tabular}{|c|c|c|c|c|c|c|c|}
\hline \multirow[b]{2}{*}{ Item } & \multicolumn{4}{|c|}{ Treatment } & \multirow[b]{2}{*}{$\mathrm{SEM}^{1}$} & \multicolumn{2}{|c|}{$P$-value ${ }^{2}$} \\
\hline & Control $(0 \%)$ & $10 \%$ RFDG & $20 \%$ RFDG & $30 \%$ RFDG & & Linear & Quadratic \\
\hline DMI (kg/d) & 21.42 & 21.78 & 21.91 & 21.13 & 1.65 & 0.73 & 0.23 \\
\hline Milk yield (kg/d) & 31.41 & 32.33 & 30.86 & 31.13 & 2.81 & 0.65 & 0.76 \\
\hline $3.5 \%$ FCM $(\mathrm{kg} / \mathrm{d})$ & 30.28 & 31.79 & 29.55 & 29.21 & 2.94 & 0.29 & 0.38 \\
\hline Fat $(\%)$ & 3.29 & 3.37 & 3.23 & 3.12 & 0.14 & 0.28 & 0.42 \\
\hline Fat yield $(\mathrm{kg} / \mathrm{d})$ & 1.03 & 1.09 & 0.99 & 0.97 & 0.11 & 0.23 & 0.33 \\
\hline Protein $(\%)$ & 2.99 & 3.01 & 3.04 & 3.03 & 0.07 & 0.35 & 0.70 \\
\hline Protein yield (kg/d) & 0.94 & 0.97 & 0.93 & 0.94 & 0.07 & 0.84 & 0.80 \\
\hline Lactose $(\%)$ & 4.76 & 4.77 & 4.74 & 4.69 & 0.12 & $<0.01$ & 0.03 \\
\hline Lactose yield (kg/d) & 1.49 & 1.54 & 1.46 & 1.46 & 0.14 & 0.48 & 0.64 \\
\hline MUN (mg/dL) & 12.64 & 13.00 & 13.07 & 13.42 & 0.93 & 0.14 & 0.98 \\
\hline
\end{tabular}

${ }^{1}$ The highest standard error of treatment means is shown.

${ }^{2} P$-values for effects of increasing levels of RFDG in diet. 
Table 7. Effect of feeding increasing levels (0 to 30\%) of reduced-fat dried distillers grains with solubles (RFDG; Poet Nutrition, Sioux Falls, $\mathrm{SD}$ ) on ruminal $\mathrm{pH}$ and concentrations of ruminal VFA and ammonia

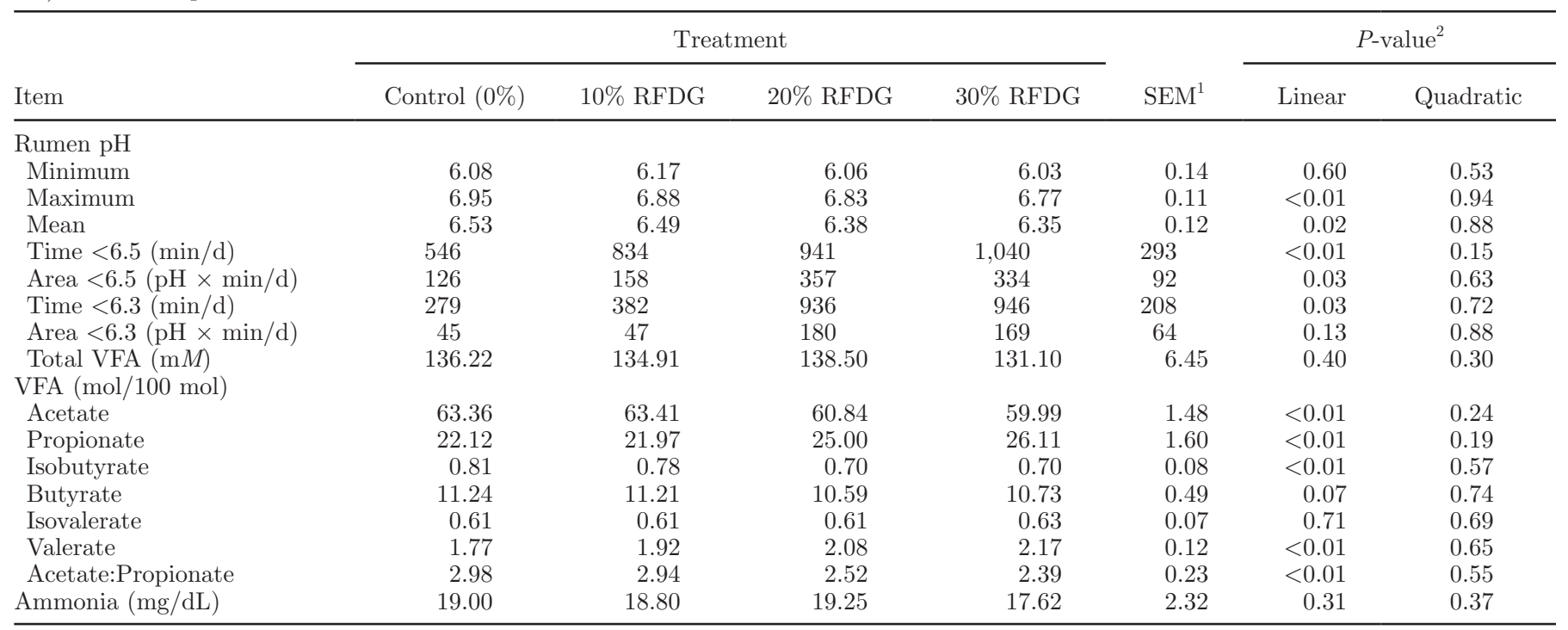

${ }^{1}$ The highest standard error of treatment means is shown.

${ }^{2} P$-values for effects of increasing levels of RFDG in diet.

are also associated with positive effects on milk fat concentration (Firkins et al., 2006). In the present study, however, the data indicated that the decrease in the concentration of ruminal acetate and butyrate did not negatively affect the percentage and yield of milk fat. On the other hand, the type of carbohydrate digested by ruminants is a decisive factor in determining the ratios of the resultant ruminal VFA. Specifically, in-

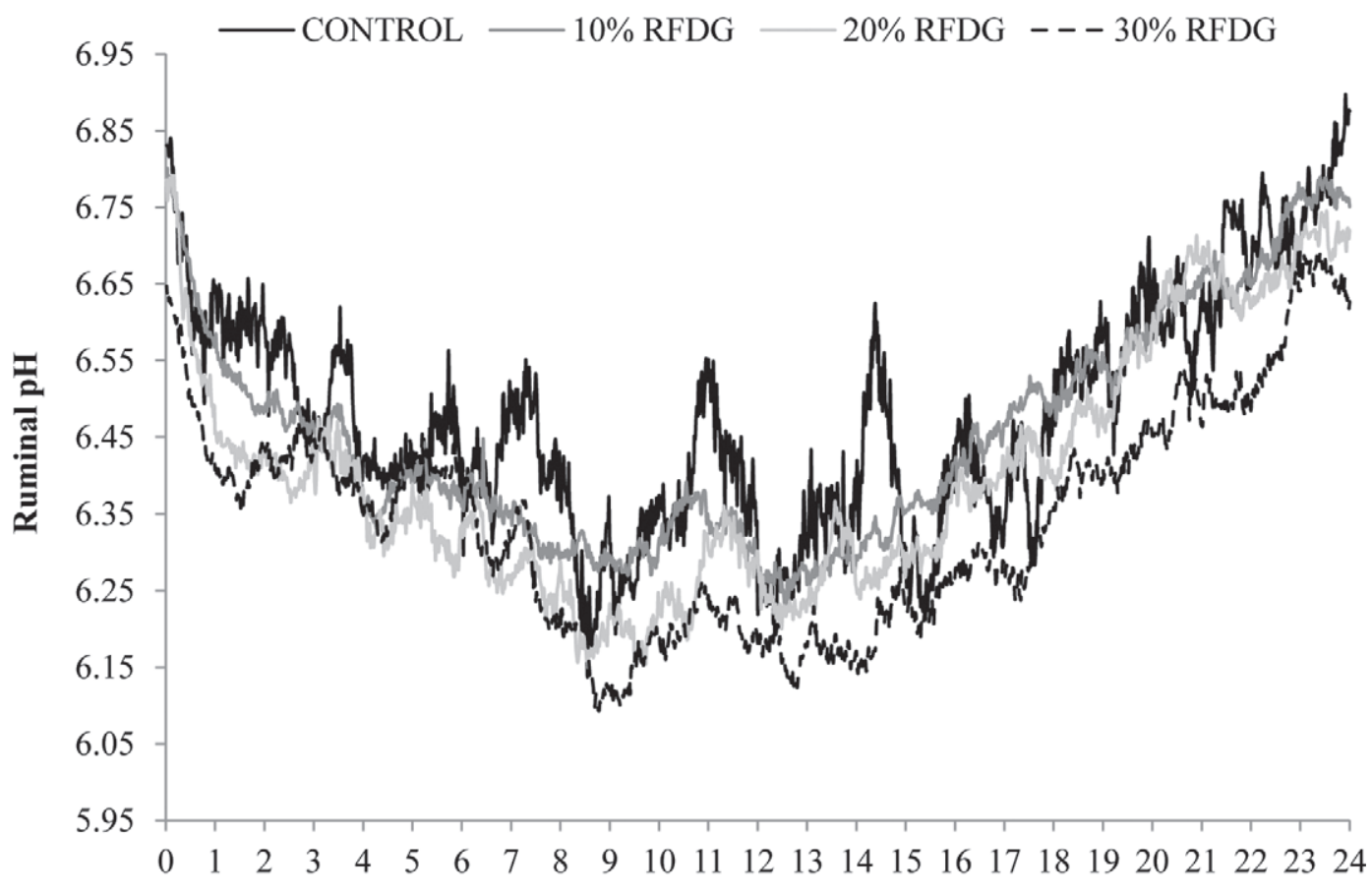

Time after feeding (h)

Figure 1. Effect of feeding increasing levels (0 to 30\%) of reduced-fat dried distillers grains with solubles (RFDG) on variation of ruminal $\mathrm{pH}$. Time after feeding $0 \mathrm{~h}$ represents $0930 \mathrm{~h}$, when TMR were offered to cows. Mean $\mathrm{pH}, P=0.02$. 
Table 8. Fecal output, nutrient intake and apparent total tract digestibility of nutrients by cows fed increasing levels (0 to $30 \%)$ of reduced-fat dried distillers grains with solubles (RFDG; Poet Nutrition, Sioux Falls, SD)

\begin{tabular}{|c|c|c|c|c|c|c|c|}
\hline Item & \multicolumn{4}{|c|}{ Treatment } & $\mathrm{SEM}^{1}$ & \multicolumn{2}{|c|}{$P$-value ${ }^{2}$} \\
\hline $\mathrm{DM}(\mathrm{kg} / \mathrm{d})$ & 6.94 & 7.20 & 5.65 & 5.61 & 0.75 & 0.15 & 0.79 \\
\hline $\mathrm{N}(\mathrm{kg} / \mathrm{d})$ & 0.202 & 0.197 & 0.152 & 0.146 & 0.02 & 0.09 & 0.88 \\
\hline $\mathrm{P}(\mathrm{g} / \mathrm{d})$ & 46.00 & 54.00 & 53.00 & 53.00 & 7.17 & 0.49 & 0.53 \\
\hline \multicolumn{8}{|l|}{$\mathrm{DM}$} \\
\hline Intake (kg/d) & 19.63 & 19.92 & 20.03 & 19.33 & 1.50 & 0.68 & 0.27 \\
\hline Digestibility (\%) & 67.7 & 67.7 & 74.9 & 75.2 & 4.4 & 0.14 & 0.96 \\
\hline \multicolumn{8}{|l|}{ NFC } \\
\hline Intake $(\mathrm{kg} / \mathrm{d})$ & 7.81 & 7.58 & 7.41 & 6.65 & 0.54 & $<0.01$ & 0.26 \\
\hline Digestibility (\%) & 89.7 & 90.1 & 92.6 & 92.7 & 1.2 & 0.07 & 0.87 \\
\hline \multicolumn{8}{|l|}{$\mathrm{NDF}$} \\
\hline Intake $(\mathrm{kg} / \mathrm{d})$ & 6.98 & 7.51 & 7.81 & 7.86 & 0.61 & 0.01 & 0.20 \\
\hline Intake (g/d) & 73.29 & 85.92 & 96.43 & 108.64 & 7.68 & $<0.01$ & 0.90 \\
\hline Digestibility (\%) & 28.08 & 35.01 & 50.18 & 50.52 & 11.51 & 0.08 & 0.62 \\
\hline
\end{tabular}

${ }^{1}$ The highest standard error of treatment means is shown.

${ }^{2} P$-values for effects of increasing levels of RFDG in diet.

creasing the concentration of starch in diets typically yields more propionate (Evans et al., 1975). In the current study, the inclusion of RFDG decreased the percentage of starch in TMR. In spite of such changes and contrasting our expectations, the molar proportion of ruminal propionate increased with RFDG inclusion, which agrees with reports by Zhang et al. (2010), but contrasts the observations of Anderson et al. (2006) and Ranathunga et al. (2010). This suggests that diets containing RFDG can support or even enhance ruminal propionate production.

The reduction in ruminal $\mathrm{pH}$ with $\mathrm{RFDG}$ inclusion may be partially explained by the reduction of TMR particle size, which likely decreased the time cows spent chewing and thus producing less saliva needed to buffer $\mathrm{pH}$ in the rumen. Overall, measurements indicate that ruminal $\mathrm{pH}$ was highest just before feeding and declined for approximately 8 to $9 \mathrm{~h}$ thereafter before gradually increasing and return to similar values before the next feeding. During this time, a gradual decrease in acid production and increased VFA absorption (Whitelaw et al., 1970), combined with salivary buffer production during rumination (Maekawa et al., 2002), returned the $\mathrm{pH}$ to near its previous value before feeding (Palmonari et al., 2010). The exact cause of the excessive foam formation and low rumen $\mathrm{pH}$ (as low as 5.5) observed in the cow consuming the $30 \%$ RFDG diet is still unclear. Previous research has indicated that development of stable, persistent ruminal foams, possessing sufficient strength for bloat to occur, depends on ruminal $\mathrm{pH}$, protein concentration, temperature, and the concentration and source of starch in the diet (Buckingham, 1970; Branine and Galyean, 1990; Cheng et al., 1998). To our knowledge, no reports have been made on the development of acidosis or excessive foam in the rumen when including RFDG in dairy rations. The reduction in TMR particle size may represent a risk for the development of ruminal acidosis (Pereira et al., 1999). In the present study, the greatest reduction in particle size was observed in the $30 \%$ RFDG TMR. In this treatment, the proportion of particles $<1.18 \mathrm{~mm}$ in experiments 1 and 2 averaged $44.8 \%$, a value considerably higher than the established guidelines (Heinrichs and Kononoff, 2002), which suggest that this proportion should not be greater than $20 \%$. It is important to note that, in spite of this reduction in TMR particle size, the average rumen $\mathrm{pH}$ values observed in this study did not fall below 6 .

\section{Apparent Total-Tract Nutrient Digestibility and Intestinal Flow of Microbial $N$}

In this study, although treatment did not affect apparent ruminal DM digestibility, increases in apparent total-tract digestibility of OM (from 67.7 to $75.2 \%$ ), NFC (from 89.7 to $92.7 \%$ ), NDF (from 44.0 to $58.0 \%$ ), and $\mathrm{N}$ (from 64.3 to $76.9 \%$ ) were observed when the level of RFDG increased from 0 to $30 \%$. An enhance- 
Table 9. Intestinal flow and apparent ruminal digestibility of DM, intestinal flow of total $\mathrm{N}$ and microbial $\mathrm{N}$ in cows fed increasing levels $(0$ to $30 \%$ ) of reduced-fat dried distillers grains with solubles (RFDG; Poet Nutrition, Sioux Falls, SD)

\begin{tabular}{|c|c|c|c|c|c|c|c|}
\hline \multirow[b]{2}{*}{ Item } & \multicolumn{4}{|c|}{ Treatment } & \multirow[b]{2}{*}{ SEM $^{1}$} & \multicolumn{2}{|c|}{$P$-value ${ }^{2}$} \\
\hline & Control $(0 \%)$ & $10 \%$ RFDG & $20 \%$ RFDG & $30 \%$ RFDG & & Linear & Quadratic \\
\hline $\mathrm{DM}(\mathrm{kg} / \mathrm{d})$ & 15.1 & 16.3 & 14.6 & 14.7 & 1.47 & 0.41 & 0.42 \\
\hline Ruminal DM digestibility (\%) & 29.4 & 25.6 & 34.5 & 29.9 & 3.2 & 0.38 & 0.87 \\
\hline Total N (g/d) & 592 & 636 & 581 & 570 & 68.0 & 0.55 & 0.50 \\
\hline \multicolumn{8}{|l|}{ Purine markers } \\
\hline \multicolumn{8}{|l|}{ DNA markers } \\
\hline Bacterial N (g/d) & 164 & 190 & 193 & 167 & 22.3 & 0.89 & 0.27 \\
\hline Protozoal N (g/d) & 43 & 30 & 39 & 51 & 13.7 & 0.51 & 0.28 \\
\hline Microbial N ${ }^{4}(\mathrm{~g} / \mathrm{d})$ & 202 & 222 & 232 & 220 & 30.9 & 0.65 & 0.60 \\
\hline Microbial $\mathrm{N}(\%$ of total $\mathrm{N})$ & 34.0 & 35.4 & 40.8 & 38.5 & 4.9 & 0.46 & 0.76 \\
\hline Yeast N (g/d) & 0.09 & 0.96 & 1.20 & 2.5 & 0.33 & $<0.01$ & 0.50 \\
\hline Calculated diet RUP ${ }^{5}(\%)$ & 49.1 & 46.5 & 50.9 & 48.1 & & & \\
\hline \multicolumn{8}{|c|}{${ }^{4}$ Microbial N estimated using DNA as microbial markers and it is the sum of bacterial and protozoal N. } \\
\hline \multicolumn{8}{|c|}{$\begin{array}{l}{ }^{5} \text { Calculated based on } \mathrm{CP} \text { intake and intestinal flow of total } \mathrm{N} \text { and microbial } \mathrm{N} \text { (when using purines as the microbial marker), not corrected wit } \\
\text { endogenous protein, which is assumed to be equal across treatments. }\end{array}$} \\
\hline \multicolumn{8}{|c|}{${ }^{6}$ Predicted by the CPM Dairy Ration Analyzer v3.0.8.1 (Cornell University, Ithaca, NY; University of Pennsylvania, Kennett } \\
\hline
\end{tabular}

ment in total-tract nutrient digestibility has been reported elsewhere (Martínez-Pérez et al., 2013) when supplementing cattle with DDGS. We suggest that the low fat levels of the RFDG improved NDF digestion (Ueda et al., 2003). In addition, the smaller particle size of RFDG increased the surface area, enhancing total-tract nutrient digestibility (Kitessa et al., 1999). The maintained ruminal DM digestibility and the sustained production of rumen ammonia when feeding RFDG may have contributed to maintain the growth of rumen microorganisms, which prefer ammonia as their source of nitrogen (Hristov and Ropp, 2003).

One of the factors that may affect rumen microbial growth is protein degradability of the diet (Stern and Hoover, 1979). Based on the intake of CP and intestinal flow of total $\mathrm{N}$ and microbial $\mathrm{N}$ (when using purines as the microbial marker), we calculated the RUP of diets fed. It was calculated by subtracting intestinal flow of microbial protein from intestinal flow of total protein; this result represented intestinal flow of feed protein. Then, the percentage of feed $\mathrm{CP}$ consumed and reaching the intestine was obtained. Estimates of RUP were $49.1,46.5,50.9$, and $48.1 \%$ for CON, 10, 20, and $30 \%$ RFDG, respectively. In this study, the percentage of MP of microbial origin (percentage of intestinal total protein flow that was represented by microbial protein) was not affected by treatment. Specifically, when purines were used as the microbial marker, es- timates were 49.0, 53.0, 49.0, and 50.0\%; when DNA was used as the microbial marker, estimates were 34.0, $35.4,40.8$, and $38.5 \%$ for CON, 10, 20, and 30\% RFDG diets, respectively. This agrees with reports from other researchers (Kelzer et al., 2009; Chibisa et al., 2012), who reported that cows consuming DDGS synthesized similar amounts of MCP compared with a control diet. When averaged across treatments, duodenal protozoal $\mathrm{N}$ flow represented $13.5 \%$ of total intestinal microbial $\mathrm{N}$. The contribution of protozoa $\mathrm{N}$ observed in this study was similar to that observed by Sylvester et al. (2005), who reported that protozoal $\mathrm{N}$ accounts for $11.9 \%$ of the duodenal flow of microbial N. Intestinal flow of yeast $\mathrm{N}(P<0.01)$ was $0.09,0.96,1.20$, and $2.5 \pm 33 \mathrm{~g} / \mathrm{d}$ for CON $, 10,20$, and $30 \%$ RFDG diets, respectively. Considering the concentration of yeastbased $\mathrm{N}$ in RFDG, animals consumed 6.5, 13.0, and $19.0 \mathrm{~g}$ of yeast $\mathrm{N} / \mathrm{d}$ when feeding 10,20 , or $30 \%$ RFDG, respectively. Therefore, our results indicate that yeast cells contained in corn ethanol byproducts are extensively degraded in the rumen. Estimates of intestinal microbial $\mathrm{N}$ flow obtained in this study were lower compared with values predicted by the CPM Dairy model, which predicted 340,360,353, and $335 \mathrm{~g}$ of microbial N/d for CON, 10, 20, and 30\% RFDG diets, respectively. The higher yield of intestinal microbial $\mathrm{N}$ when using purines as microbial marker may indicate that nonmicrobial purines are reaching the duodenum 
(Belanche et al., 2011b). It is also likely that the DNA markers used are not present in all rumen microbial species, resulting in an underestimation of microbial $\mathrm{N}$. It has been suggested, however, that the use of DNA markers represents a good option when the purpose is the estimation of bacterial and protozoal $\mathrm{N}$ separately (Belanche et al., 2011a,b).

\section{CONCLUSIONS}

This study was designed (1) to evaluate the effect of RFDG on lactation performance, rumen fermentation, intestinal microbial $\mathrm{N}$ supply, and total-tract nutrient digestibility; and (2) to compare the estimates of microbial N using purines or DNA as microbial markers. Results indicate that DNA markers yield lower microbial $\mathrm{N}$ compared with purines, possibly because the DNA markers utilized in this study did not account for all rumen microbial species reaching the small intestine. In addition, when RFDG was included in dairy rations, lactation performance was maintained, rumen VFA concentrations and intestinal microbial N supply were not affected, and total-tract nutrient digestibility tended to increase. Overall, this study demonstrates that RFDG is an effective alternative energy and protein feed source for the dairy industry.

\section{REFERENCES}

Allen, D. M., and R. J. Grant. 2000. Interactions between forage and wet corn gluten feed as sources of fiber in diets for lactating dairy cows. J. Dairy Sci. 83:322-331.

Anderson, D. E., and D. M. Rings. 2009. Ruminant field anesthesia. Page 556 in Current Veterinary Therapy Food Animal Practice 5. Saunders Elsevier, St. Louis, MO.

Anderson, J. L., D. J. Schingoethe, K. F. Kalscheur, and A. R. Hippen. 2006. Evaluation of dried and wet distillers grains included at two concentrations in the diets of lactating dairy cows. J. Dairy Sci. 89:3133-3142.

AOAC International. 2000. Official Methods of Analysis. Vol. 1 and 2. 17th ed. AOAC International, Gaithersburg, MD.

AOAC International. 2006. Official Methods of Analysis. 18th ed. AOAC International, Gaithersburg, MD.

Aschenbach, J. R., G. B. Penner, F. Stumpff, and G. Gäbel. 2011. Ruminant Nutrition Symposium: Role of fermentation acid absorption in the regulation of ruminal pH. J. Anim. Sci. 89:1092-1107.

Bauman, D. E., and J. M. Griinari. 2003. Nutritional regulation of milk fat synthesis. Annu. Rev. Nutr. 23:203-227.

Belanche, A., L. Abecia, G. Holtrop, J. A. Guada, C. Castrillo, G. de la Fuente, and J. Balcells. 2011a. Study of the effect of presence or absence of protozoa on rumen fermentation and microbial protein contribution to the chyme. J. Anim. Sci. 89:4163-4174.

Belanche, A., G. de la Fuente, D. R. Yáñez-Ruiz, C. J. Newbold, L. Calleja, and J. Balcells. 2011b. Technical note: The persistence of microbial-specific DNA sequences through gastric digestion in lambs and their potential use as microbial markers. J. Anim. Sci. $89: 2812-2816$

Branine, M. E., and M. L. Galyean. 1990. Influence of grain and monensin supplementation on ruminal fermentation, intake, digesta kinetics and incidence and severity of frothy bloat in steers grazing winter wheat pastures. J. Anim. Sci. 68:1139-1150.
Broderick, G. A., and N. R. Merchen. 1992. Markers for quantifying microbial protein synthesis in the rumen. J. Dairy Sci. 75:26182632.

Buckingham, J. H. 1970. Effect of pH, concentration and temperature on the strength of cytoplasmic protein foams. J. Sci. Food Agric. $21: 441-445$.

Castillo-Lopez, E., T. J. Klopfenstein, S. C. Fernando, and P. J. Kononoff. 2013. In vivo determination of rumen undegradable protein of dried distillers grains with solubles and evaluation of duodenal microbial crude protein flow. J. Anim. Sci. 91:924-934.

Castillo-Lopez, E., P. J. Kononoff, and J. Miner. 2010. Short communication: Detection of yeast DNA in omasal digesta of dairy cows consuming dried distillers grains and solubles. J. Dairy Sci. 93:5926-5929.

Cheng, K. J., T. A. McAllister, J. D. Popp, A. N. Hristov, Z. Mir, and H. T. Shin. 1998. A review of bloat in feedlot cattle. J. Anim. Sci. 76:299-308.

Chibisa, G. E., D. A. Christensen, and T. Mutsvangwa. 2012. Effects of replacing canola meal as the major protein source with wheat dried distillers grains with solubles on ruminal function, microbial protein synthesis, omasal flow, and milk production in cows. J. Dairy Sci. 95:842-849.

Evans, E., J. G. Buchanan-Smith, and G. K. Macleod. 1975. Postprandial patterns of plasma glucose, insulin and volatile fatty acids in ruminants fed low- and high-roughage diets. J. Anim. Sci. 41:1474-1479

Firkins, J. L., A. N. Hristov, M. B. Hall, G. A. Varga, and N. R. StPierre. 2006. Integration of ruminal metabolism in dairy cattle. J. Dairy Sci. 89(E. Suppl.):E31-E51.

Hall, M. B. 2009. Analysis of starch, including maltooligosaccharides, in animal feeds: A comparison of methods and a recommended method for AOAC collaborative study. J. AOAC Int. 92:42-49.

Harmon, D. L., and C. J. Richards. 1997. Considerations for gastrointestinal cannulations in ruminants. J. Anim. Sci. 75:2248-2255.

Harvatine, D. I., J. E. Winkler, M. Devant-Guille, J. L. Firkins, N. R. St-Pierre, B. S. Oldick, and M. L. Eastridge. 2002. Whole linted cottonseed as a forage substitute: Fiber effectiveness and digestion kinetics. J. Dairy Sci. 85:1988-1999.

Heinrichs, A. J. and P. J. Kononoff. 2002. Evaluating particle size of forages and TMRs using the Penn State Particle Size Separator. Technical Bulletin DAS 96-20. College of Agriculture Science, Cooperative Extension, Pennsylvania State University, University Park.

Hollmann, M., M. S. Allen, and D. K. Beede. 2011. Diet fermentability influences lactational performance responses to corn distillers grains: A meta-analysis. J. Dairy Sci. 94:2007-2021.

Hristov, A. N., and G. Broderick. 1996. Synthesis of microbial protein in ruminally cannulated cows fed alfalfa silage, alfalfa hay or corn silage. J. Dairy Sci. 79:1627-1637.

Hristov, A. N., T. A. McAllister, D. R. Ouellet, and G. A. Broderick. 2005. Comparison of purines and nitrogen-15 as microbial flow markers in beef heifers fed barley- or corn-based diets. Can. J. Anim. Sci. 85:211-222.

Hristov, A. N., and J. K. Ropp. 2003. Effect of dietary carbohydrate composition and availability on utilization of ruminal ammonia nitrogen for milk protein synthesis in dairy cows. J. Dairy Sci. $86: 2416-2427$

Huhtanen, P., K. Kaustell, and S. Jaakkola. 1994. The use of internal markers to predict total digestibility and duodenal flow of nutrients in cattle given six different diets. Anim. Feed Sci. Technol. 48:211-227.

Janicek, B. N., P. J. Kononoff, A. M. Gehman, and P. H. Doane. 2008. The effect of feeding dried distillers grains plus solubles on milk production and excretion of urinary purine derivatives. J. Dairy Sci. 91:3544-3553.

Kelzer, J. M., P. J. Kononoff, A. M. Gehman, L. O. Tedeschi, K. Karges, and M. L. Gibson. 2009. Effects of feeding three types of corn-milling coproducts on milk production and ruminal fermentation of lactating Holstein cattle. J. Dairy Sci. 92:5120-5132. 
Kitessa, S., P. C. Flinn, and G. G. Irish. 1999. Comparison of methods used to predict the in vivo digestibility of feeds in ruminants. Aust. J. Agric. Res. 50:825-841.

Klopfenstein, T. J., G. E. Erickson, and V. R. Bremer. 2008. Boardinvited review: Use of distillers byproducts in the beef cattle feeding industry. J. Anim. Sci. 86:1223-1231.

Kononoff, P. J., and K. J. Hanford. 2006. Estimating statistical power of mixed models used in dairy nutrition experiments. J. Dairy Sci. 89:3968-3971.

Maekawa, M., K. A. Beauchemin, and D. A. Christensen. 2002. Effect of concentrate level and feeding management on chewing activities, saliva production, and ruminal $\mathrm{pH}$ of lactating dairy cows. J. Dairy Sci. 85:1165-1175.

Majoni, S., T. Wang, and L. A. Johnson. 2011. Physical and chemical processes to enhance oil recovery from condensed corn distillers solubles. J. Am. Oil Chem. Soc. 88:425-434.

Makkar, H. P. S., and K. Becker. 1999. Purine quantification in digesta from ruminants by spectrophotometric and HPLC methods. Br. J. Nutr. 81:107-112.

Martínez-Pérez, M. F., D. Calderón-Mendoza, A. Islas, A. M. Encinias, F. Loya-Olguín, and S. A. Soto-Navarro. 2013. Effect of corn dry distiller grains plus solubles supplementation level on performance and digestion characteristics of steers grazing native range during forage growing season. J. Anim. Sci. 91:1350-1361.

May, M. L., J. C. DeClerck, M. J. Quinn, N. DiLorenzo, J. Leibovich, D. R. Smith, K. E. Hales, and M. L. Galyean. 2010. Corn or sorghum wet distillers grains with solubles in combination with steam-flaked corn: Feedlot cattle performance, carcass characteristics, and apparent total tract digestibility. J. Anim. Sci. 88:24332443.

McDougall, E. I. 1948. The composition and output of sheep's saliva. Biochem. J. 43:99-109.

Mjoun, K., K. F. Kalscheur, A. R. Hippen, and D. J. Schingoethe. 2010a. Performance and amino acid utilization of early lactation dairy cows fed regular or reduced-fat dried distillers grains with solubles. J. Dairy Sci. 93:3176-3191.

Mjoun, K., K. F. Kalscheur, A. R. Hippen, D. J. Schingoethe, and D. E. Little. 2010b. Lactation performance and amino acid utilization of cows fed increasing amounts of reduced-fat dried distillers grains with solubles. J. Dairy Sci. 93:288-303.

Noordsy, J. L., and N. K. Ames. 2006. Rumenotomy, fistulation, cannulation, and pericardiotomy in cattle. Pages 118-120 in Food Animal Surgery. 4th ed. Veterinary Learning Systems, Yardley, PA.

Palmonari, A., D. M. Stevenson, D. R. Mertens, C. W. Cruywagen, and P. J. Weimer. 2010. pH dynamics and bacterial community composition in the rumen of lactating dairy cows. J. Dairy Sci. 93:279-287.

Penner, G. B., K. A. Beauchemin, and T. Mutsvangwa. 2006. An evaluation of the accuracy and precision of a stand-alone submersible continuous ruminal $\mathrm{pH}$ measurement system. J. Dairy Sci. 89:2132-2140.

Pereira, M. N., E. F. Garrett, G. R. Oetzel, and L. E. Armentano. 1999. Partial replacement of forage with nonforage fiber sources in lactating cow diets. I. Performance and health. J. Dairy Sci. 82:2716-2730

Ramirez-Ramirez, H. A., A. R. Geis, C. S. Heine, K. J. Clark, A. M. Gehman, and P. J. Kononoff. 2011. Storage conditions of wet corn distillers' grains with solubles in combination with other feeds and understanding the effects on performance of lactating dairy cows. Can. J. Anim. Sci. 91:331-339.

Ranathunga, S. D., K. F. Kalscheur, A. R. Hippen, and D. J. Schingoethe. 2010. Replacement of starch from corn with nonforage fiber from distillers grains and soyhulls in diets of lactating dairy cows. J. Dairy Sci. 93:1086-1097.

Robinson, P. H., D. F. Smith, and C. J. Sniffen. 1985. Development of a one-piece reentrant cannula for the proximal duodenum of dairy cows. J. Dairy Sci. 68:986-995.

Schingoethe, D. J., K. F. Kalscheur, A. R. Hippen, and A. D. Garcia. 2009. Invited review: The use of distillers products in dairy cattle diets. J. Dairy Sci. 92:5802-5813.

Shabi, Z., H. Tagari, M. Murphy, I. Bruckental, S. Mabjeesh, S. Zamwel, K. Celik, A. Arieli, and H. Tagari. 2000. Partitioning of amino acids flowing to the abomasum into feed, bacterial, protozoal, and endogenous fractions. J. Dairy Sci. 83:2326-2334.

Stern, M. D., and W. H. Hoover. 1979. Methods for determining and factors affecting rumen: A review. J. Anim. Sci. 49:1590-1603.

Supelco Inc. 1975. Supelco Bulletin 749E. Supelco Inc., Bellefonte, PA.

Sylvester, J. T., S. K. R. Karnati, Z. Yu, C. J. Newbold, and J. L. Firkins. 2005. Evaluation of a real-time PCR assay quantifying the ruminal pool size and duodenal flow of protozoal nitrogen. J. Dairy Sci. 88:2083-2095.

Taylor, C. C., and M. S. Allen. 2005. Corn grain endosperm type and brown midrib 3 corn silage: Site of digestion and ruminal digestion kinetics in lactating cows. J. Dairy Sci. 88:1413-1424.

Thomas, P. C., and P. A. Martin. 1988. The influence of nutrient balance on milk yield and composition. Pages $97-118$ in Nutrition and Lactation in the Dairy Cow. P. C. Garnsworthy, ed. Butterworths, London, UK.

Turner, A. S., and C. W. McIlwraith. 1989. Anesthesia and fluid therapy. Pages 10-12 in Techniques in Large Animal Surgery. 2nd ed. Lea \& Febiger, Philadelphia, PA.

Ueda, K., A. Ferlay, J. Chabrot, J. J. Loor, Y. Chilliard, and M. Doreau. 2003. Effect of linseed oil supplementation on ruminal digestion in dairy cows fed diets with different forage:concentrate ratios. J. Dairy Sci. 86:3999-4007.

Van Soest, P. J., J. B. Robertson, and B. A. Lewis. 1991. Methods for dietary fiber, neutral detergent fiber, and nonstarch polysaccharides in relation to animal nutrition. J. Dairy Sci. 74:3583-3597.

Whitelaw, F. G., J. Hyldgaard-Jensen, R. S. Reid, and M. G. Kay. 1970. Volatile fatty acid production in the rumen of cattle given an all-concentrate diet. Br. J. Nutr. 24:179-195.

Wildman, E. E., G. M. Jones, P. E. Wagner, H. F. Troutt Jr., and T. N. Lesch. 1982. A dairy cow body condition scoring system and its relationship to selected production characteristics. J. Dairy Sci. 65:495-501.

Yang, C. M. J., and G. A. Varga. 1989. Effect of three concentrate feeding frequencies on rumen protozoa, rumen digesta kinetics, and milk yield in dairy cows. J. Dairy Sci. 72:950-957.

Yu, Y., C. Lee, K. Kim, and S. Hwang. 2005. Group-specific primer and probe sets to detect methanogenic communities using quantitative real-time polymerase chain reaction. Biotechnol. Bioeng. 89:670-679.

Yu, Z., and M. Morrison. 2004. Improved extraction of PCR-quality community DNA from digesta and fecal samples. Biotechniques 36:808-812.

Zhang, S. Z., G. B. Penner, M. Abdelqader, and M. Oba. 2010. Effects of feeding alfalfa hay on chewing, rumen $\mathrm{pH}$, and milk fat concentration of dairy cows fed wheat dried distillers grains with solubles as a partial substitute for barley silage. J. Dairy Sci. 93:3243-3252.

Zinn, R. A., and F. N. Owens. 1986. A rapid procedure for purine measurement and its use for estimating net ruminal protein synthesis. Can. J. Anim. Sci. 66:157-166. 